\title{
Phenolic Compounds in Cambodian Leaves and Flowers (Plumeria acuminata Ait.) at Various Times Decomposition
}

\author{
Yuliani $^{*}$, Yuni Sri Rahayu, and Sari Kusuma Dewi \\ Department of Biology, Faculty of Mathematics and Natural Sciences, Universitas Negeri Surabaya, Indonesia.
}

\begin{abstract}
Phenol compounds are secondary metabolic compounds produced by plants and can cause the surrounding environment to change. This study aims to find out the content of phenolic compounds in cambodian leaves and flowers (Plumeria acuminata Ait.) that are decomposition at different times. The experiment used a complete Randomized Design of factorial patterns consisting of the source factor of old leaf extract, deciduous leaves and flowers and decomposition period $(0,1,2$, and 3 weeks) with 3 repeats, so that there were 12 combinations of treatments. Data analysis using ANOVA and continued with DMRT. The results showed that cambodian leaves and flowers contained phenol compounds identified as benzoate acid, salicylic acid, vanilic acid and coumarin.
\end{abstract}

Keywords: Phenol compounds, ANOVA, Randomized Design

\section{Introduction}

Plumeria acuminata known as Cambodia is a type of gummy plant that lives at an altitude of 1-1000 m above sea level. Plumeria is native to tropical America, including the family Apocynaceae and is spread throughout Indonesia. Plumeria is used as a medicinal ingredient, especially the bark, leaves and sap are used as a remedy for ulcers, berries, malaria and so on [1].

Plumeria acuminata grows both in sub-tropical to tropical climates, with its distinctive floral fragrantness, and in the soil where plumeria grows there are often no herbs or weeds that live mainly in places where cambodian leaves and flowers fall and decompose. This is thought to be because the decomposition of cambodian leaves and flowers

in addition to donating nutrients into the soil also produce compounds that can inhibit the growth of plants around it. The chemical compounds found in plumeria are Terpenoids, steroids, phenols, glycosides iridoids, plumericin, isoplumericin, $\beta$-dihydroplumericin and $\beta$ dihydroplumericinic acid. [2],[3] obtained from plumeria leaf extract. Research into the genus Plumeria is often done because of its use as a drug and antibiotic ingredient. Research of [4] confirms that Plumeria leaf extract results in antimutagens and antifungals. From various studies it is known that Plumeria contains compounds lupeol, phenol, plumericins, steroid, cardiac glycoside and sapogenin [5].

Organic material added to the soil affects plant growth due to its influence on temperature, physics, chemistry and soil biology. The addition of organic materials into the soil in addition to providing a source of nutrients and spurring the activity of soil microorganisms can also improve soil structure, increase aeration or soil moisture content. In addition, decomposition of organic materials will also affect its environmental conditions. During decomposition, the nutrient content in the soil will experience dynamics, in addition, organic acid acids such as citric acid, oxalate, malic and so on cause a decrease in $\mathrm{pH}$ and affect the activity of soil microbes [6].

Decomposition of organic materials also releases toxic compounds against plants and organisms that are associated. For example, five phenol compounds resulting from the decomposition of rice straw namely phydroxybenzoic, p-comaric, vanillic, ferulic and hydroxyphenylacetic in low concentrations can inhibit the growth of various plant species [5].

Phenols are secondary metabolite compounds that include a number of compounds that generally have an aromatic ring with one or more hydroxyl, carboxyl and methoxyl [7] phenol compounds can be toxic depending on the levels and concentrations used. This research aims to find out the content and composition of phenolic compounds in cambodian leaves and flowers that are decomposition at different times.

\footnotetext{
*Corresponding author : yuliani@unesa.ac.id
} 


\section{Methods}

This study used a Complete Randomized design with two factors namely the decomposition period factor (aquades, decomposition 1 week, decomposition 2 weeks, decomposition 3 weeks) and extract source factor (old leaves, deciduous leaves, and flowers) with three repeats. The research stage includes the manufacture of cambodian leaf and flower extracts accompanied by analysis of phenol compounds.

Stage of extract making. Cambodian leaves and flowers are cleaned, weighed as much as 200 grams, cut into pieces and given water as much as $300 \mathrm{ml}$ then mashed. After that it was filtered with Whatman's paper. Then analyzed to find out the content. For decomposition treatment, 200 grams of cambodian leaves and flowers are cut into small pieces, put in a container and given $300 \mathrm{ml}$ of water. Decomposed for $1,2,3$ weeks and the water will be analyzed to find out the phenol content.

The analysis stage of phenol compounds [8] in the following way : 1) $50 \mathrm{ml}$ sample hydrolyzed in an acidic atmosphere with $50 \mathrm{ml} \mathrm{HCl} 2 \mathrm{M}$ for 30 minutes with a temperature of $60 \mathrm{C}$, then cooled and filtered, 2) Phenols are released in extraction with ethyl ether, 3) then given aquades as much as $10 \mathrm{ml}$, in shakes and aquades are removed. The water extract is then evaporated to dry, 4) the rest of the evaporation is dissolved in ether, then injected into Packard gas-Hewlet chromatography with a FID detector (Flame Ionitation Detector) using 4 standard solutions namely benzoate acid, salicylic acid, vanilic acid and coumarin. Data analysis using ANOVA and continued using DMRT.

\section{Results And Discussion}

\subsection{Content of Benzoate Acid}

Anava's results showed that the effect of treatment (extract source, decomposition period and interaction) on benzoate acid content in cambodian leaves and flowers are significants.

Table 1. Content of benzoate acid in the leaves and flowers of Plumeria acuminata (ppm)

\begin{tabular}{|l|l|l|l|l|l|}
\hline Treatment & D0 & D1 & D2 & D3 & Average \\
\hline A1 & $\begin{array}{l}506,3 \\
\text { de }\end{array}$ & $\begin{array}{l}597,7 \\
\text { de }\end{array}$ & $\begin{array}{l}878,8 \\
\text { de }\end{array}$ & $13453 \mathrm{~cd}$ & $831,5 \mathrm{~b}$ \\
\hline A2 & $\begin{array}{l}305,9 \\
\mathrm{e}\end{array}$ & $\begin{array}{l}295,9 \\
\mathrm{e}\end{array}$ & $\begin{array}{l}329,2 \\
\mathrm{e}\end{array}$ & $770,8 \mathrm{de}$ & $425,4 \mathrm{~b}$ \\
\hline B & $\begin{array}{l}509,1 \\
\mathrm{de}\end{array}$ & $\begin{array}{l}2169,0 \\
\mathrm{bc}\end{array}$ & $\begin{array}{l}2438,8 \\
\mathrm{ab}\end{array}$ & $3055,5 \mathrm{a}$ & $2043,1 \mathrm{a}$ \\
\hline Average & $\begin{array}{l}440,4 \\
\mathrm{c}\end{array}$ & $\begin{array}{l}1020,9 \\
\mathrm{~b}\end{array}$ & $\begin{array}{l}1214,9 \\
\mathrm{~b}\end{array}$ & $1723,9 \mathrm{a}$ & \\
\hline
\end{tabular}

1. The numbers followed by the same letter in both columns and rows do not differ markedly at the test level of 0.05 according to DMRT.

2. $\mathrm{A} 1=$ Old leaves, $\mathrm{A} 2=$ Deciduous leaves, $\mathrm{B}=$ Flowers, D0 $=$ Aquades, D1 $=$ Decomposition 1 week, D2 $=$ Decomposition 2 weeks, D3 $=$ Decomposition 3 weeks.
The data on table 1 showed that the highest benzoate acid content was in the combination of BD3 and the lowest A2D1. The results also showed that the content of benzoate acid continued to increase until 3 weeks decomposition, in addition, flowers had the highest benzoic acid content followed by old leaves and the lowest was deciduous leaves.

\subsection{Content of Salicylic Acid}

Table 2. Content of Salicylic acid in Plumeria acuminata (ppm)

\begin{tabular}{|l|l|l|l|l|l|}
\hline Treatment & D0 & D1 & D2 & D3 & Average \\
\hline A1 & $315 \mathrm{c}$ & $903 \mathrm{c}$ & $\begin{array}{l}3176 \\
\mathrm{bc}\end{array}$ & $\begin{array}{l}8195 \\
\mathrm{~b}\end{array}$ & $3147 \mathrm{ab}$ \\
\hline A2 & $\begin{array}{l}2551 \\
\mathrm{c}\end{array}$ & $2114 \mathrm{c}$ & $1792 \mathrm{c}$ & $\begin{array}{l}13853 \\
\mathrm{a}\end{array}$ & $5077 \mathrm{a}$ \\
\hline B & $334 \mathrm{c}$ & $952 \mathrm{c}$ & $901 \mathrm{c}$ & $\begin{array}{l}1105 \\
\mathrm{c}\end{array}$ & $823 \mathrm{~b}$ \\
\hline Average & $\begin{array}{l}1067 \\
\mathrm{~b}\end{array}$ & $1323 \mathrm{~b}$ & $\begin{array}{l}1956 \\
\mathrm{~b}\end{array}$ & $\begin{array}{l}7718 \\
\mathrm{a}\end{array}$ & \\
\hline
\end{tabular}

The results showed that salicylic acid was present in all treatments. The combination of 3 weeks decomposition time treatment with the source of deciduous leaf extract exerts the most influence on salicylic acid content followed by 3 weeks decomposition old leaves. The lowest result is obtained from the combination of old leaves with water (A1D0). Anava's results showed that the decomposition period, treatment of extract sources and interactions had a noticeable effect on salicylic acid content.

\subsection{Content of Vanilic Acid}

The average content of vanilic acid can be seen in table 3 . This suggests that vanilic acid is found only in flowers during all decomposition times, while in old leaves, and deciduous leaves are not found in vanilic acid. Anava results showed that the treatment of extract sources had a real effect while the decomposition period did not have a noticeable effect on the content of vanilic acid.

Table. 3 Content of Vanilic acid in Plumeria acuminata (ppm)

\begin{tabular}{|l|l|l|l|l|l|}
\hline Treatment & D0 & D1 & D2 & D3 & Average \\
\hline A1 & $0,00 \mathrm{~b}$ & $0,00 \mathrm{~b}$ & $0,00 \mathrm{~b}$ & $0,00 \mathrm{~b}$ & $0,00 \mathrm{~b}$ \\
\hline A2 & $0,00 \mathrm{~b}$ & $0,00 \mathrm{~b}$ & $0,00 \mathrm{~b}$ & $0,00 \mathrm{~b}$ & $0,00 \mathrm{~b}$ \\
\hline B & $473,4 \mathrm{a}$ & $576,3 \mathrm{a}$ & $582,3 \mathrm{a}$ & $\begin{array}{l}376,7 \\
\text { ab }\end{array}$ & $502,17 \mathrm{a}$ \\
\hline Average & $157,81 \mathrm{a}$ & $192,10 \mathrm{a}$ & $\begin{array}{l}194,09 \\
\mathrm{a}\end{array}$ & $\begin{array}{l}125,56 \\
\mathrm{a}\end{array}$ & \\
\hline
\end{tabular}

\subsection{Content of Coumarine}

Based on the results of anava, the treatment of extract sources and decomposition period has no effect on the content of coumarin in Plumeria acuminata. The highest coumarin content is found in deciduous leaves with a decomposition of 2 weeks, while the lowest in flowers with water as in table 4 . 
Table 4. Content of Coumarine in Plumeria acuminata (ppm)

\begin{tabular}{|l|l|l|l|l|l|}
\hline Treatment & D0 & D1 & D2 & D3 & Average \\
\hline A1 & $539,7 \mathrm{a}$ & $632,9 \mathrm{a}$ & $648,1 \mathrm{a}$ & $694,6 \mathrm{a}$ & $628,84 \mathrm{a}$ \\
\hline A2 & $512,2 \mathrm{a}$ & $655,3 \mathrm{a}$ & $739,9 \mathrm{a}$ & $492,1 \mathrm{a}$ & $599,88 \mathrm{a}$ \\
\hline B & $492,0 \mathrm{a}$ & $610,3 \mathrm{a}$ & $502,3 \mathrm{a}$ & $534,4 \mathrm{a}$ & $534,77 \mathrm{a}$ \\
\hline Average & $514,66 \mathrm{a}$ & $630,1 \mathrm{a}$ & $632,3 \mathrm{a}$ & $573,72 \mathrm{a}$ & \\
\hline
\end{tabular}

The results of the analysis showed that the content of phenol compounds was influenced by the source of the extract and the decomposition period in real terms. Qualitatively benzoate acid, salicylic acid and coumarin are found in all three sources of the extract namely old leaves, deciduous leaves and flowers. While vanilic acid is only found in cambodian flowers. Flowers have the highest content of benzoate acid and vanilic acid, while the highest content of salicylic acid and coumarin is found in deciduous leaves and flowers. Overall the content of phenol compounds (salicylic acid, benzoate acid, vanilicc acid and coumarin) was highest found in deciduous leaves that were decomposition for 3 weeks, followed by old leaves and flowers decomposition for 3 weeks.

The content of phenol compounds present in plants is influenced by the type of organ and the age of plant organs. This is because the metabolism of secondary metabolites results in different organs or tissue ages. So it can be said that the levels of inhibitory compounds in the body of plants are not the same. Factors that affect inhibitory compounds in the plant body include the quality, quantity of light and length of irradiation, type and age of organs, nutrient deficiency conditions, lack of water, temperature, genetic properties of plants and others [9] [10]

In addition to the source of the extract, the content of phenolic compounds in Plumeria is influenced by the decomposition period, the content of phenolic compounds increases in levels along with increasing decomposition time. From the table it appears that the content of benzoate acid, and salicylic acid increases in levels along with increasing decomposition time. The process of rapid decomposition of organic matter depends on the type of organ that accumulates. The high content of lignin and wax in plant materials will slow down the decomposition process, because lignin is more resistant to decomposition than carbohydrates and proteins [11] this is seen in cambodian flowers that decompose faster than leaves. In the decomposition process there is a change from a phenol compound to another phenol, for example ferulatic acid in the decomposition process can turn into vanilic acid. Furthermore, vanilic acid in the decomposition process will become protocatekuat (rice), this change that results in the release of toxic compounds into the environment and affects the surrounding plants [10], [12].

\section{Conclusion}

1. Cambodian leaves and flowers have phenol compounds identified as benzoic acid, salicylic acid, vanilic acid and coumarin. The largest content of phenol compounds is found in deciduous leaves that have been decomposed for 3 weeks, and the lowest phenol content is found in old leaves that have not undergone decomposition.

2. Decomposition time affects the content of phenol compounds. The more deposition time, the more the content of phenol compounds.

All the authors are thankful to the Ministry of Education and Culture, Research and Technology which has funded The Excellent Applied Research of Higher Education, so that this research can be carried out.

\section{References}

[1] Sirisha K, Rajendra Y, Ganathi P, Soujanya K, and Yasmeen N. RJPBS. 44 (2013)

[2] Budaya PYA, Astiti NPA, Kriswiyanti E. Jurnal Biologi. 191 (2015)

[3] Manjusha C., Vipin K. Surender, S. Journal IJBAR 56 (2014)

[4] Berty O, Rahmawati, Linda R. Jurnal Laora Medika. 12 (2017)

[5] Shofi M, Suwitasari F, Istiqomah N. Jurnal Biologi. 132 (2020)

[6] Guoan.W, Yufu, J, Wei L. Scientific Report,5 11043 (2015)

[7] Farooque AM, Mazunder A, Shambhawee S, and Mazumber R. IJRPC 22 (2012)

[8] Harbourne JB. Metode Fitokimia (1987)

[9] Ahmad J, M.A. Chosin, Kwang H.K. Jurnal Hayati 132 (2006)

[10] Rice, E.L. Allelopathy. (1984)

[11] Vermaas JV, Petridis L, Qi X, Schulz R, Lindner B, and Smith JC. Biotechnol Biofuels 8217 (2015).

[12] T. Ohno. J of Env Qua.30 5 (2001) 